\title{
Flower morphology, nectar features, and hummingbird visitation to Palicourea crocea (Rubiaceae) in the Upper Paraná River floodplain, Brazil
}

\author{
LUCIANA B. MENDONÇA ${ }^{1}$ and LUIZ DOS ANJOS ${ }^{2}$ \\ ${ }^{1}$ Universidade Estadual de Maringá, Pós-Graduação em Ecologia de Ambientes Aquáticos Continentais, \\ Av. Colombo, 5790, Bloco G90, 87020-900 Maringá, PR, Brasil \\ ${ }^{2}$ Universidade Estadual de Londrina, Depto de Biologia Animal e Vegetal, \\ Laboratório de Ornitologia e Bioacústica, Cx. Postal 6001, 86051-970 Londrina, PR, Brasil \\ Manuscript received on March 18, 2005; accepted for publication on July 25, 2005; \\ presented by NANUZA L. DE MENEZES
}

\begin{abstract}
We investigated flower morphology, nectar features, and hummingbird visitation to Palicourea crocea (Rubiaceae), a common ornithophilous shrub found in the riparian forest understory in the Upper Paraná River floodplain, Brazil. Flowers are distylous and the style-stamen dimorphism is accompanied by other intermorph dimorphisms in corolla length, anther length, and stigma lobe length and form. We did not observe strict reciprocity in the positioning of stigma and anthers between floral morphs. Flowering occurred during the rainy season, October to December. Nectar standing crop per flower was relatively constant throughout the day, which apparently resulted in hummingbirds visiting the plant throughout the day. Energetic content of the nectar in each flower (66.5J) and that required daily by hummingbird visitors (up to $30 \mathrm{~kJ}$ ) would oblige visits to hundreds of flowers each day, and thus movements between plants that should result in pollen flow. Three hummingbird species visited the flowers: the Gilded Sapphire (Hylocharis chrysura), the Black-throated Mango (Anthracothorax nigricollis), and the Glittering-bellied Emerald (Chlorostilbon aureoventris). The frequency of hummingbird visitation, nectar features, and the scarcity of other hummingbird-visited flowers in the study area, indicate that $P$. crocea is an important nectar resource for short-billed hummingbirds in the study site.
\end{abstract}

Key words: bird-plant interactions, heterostyly, pollination, Brazilian Atlantic forest, riparian vegetation, conservation.

\section{INTRODUCTION}

Rubiaceae include species with floral features (morphological and energetic) related to a variety of pollinating agents including bees, butterflies, moths and hummingbirds (Passos and Sazima 1995, Stone 1996, Machado and Loiola 2000, Wesseling et al. 2000). Hummingbird pollination is frequent among

Correspondence to: Luciana Baza Mendonça

E-mail: lucianabaza@yahoo.com.br the Neotropical members of this family, having been recorded for species of Hamelia, Isertia, Kerianthera, Manettia, Ferdinandusa, Psychotria, Palicourea, Pentagonia, and Sabicea (Feinsinger 1978, Marques-Souza et al. 1993, Passos and Sazima 1995, Murcia and Feinsinger 1996, Contreras and Ornelas 1999, Buzato et al. 2000, Castro and Oliveira 2001, McDade and Weeks 2004a, Ornelas et al. 2004, Teixeira and Machado 2004). 
Palicourea Aublet is a Neotropical genus (closely related to Psychotria, Taylor 1997) comprising about 200 species of shrubs or small trees that typically occur in the understory and subcanopy of moist to wet forest; most species exhibit floral traits consistent with hummingbird-pollination (Sobrevila et al. 1983, Murcia and Feinsinger 1996, Ree 1997, Taylor 1997, Contreras and Ornelas 1999). According to Taylor (1997) nearly all Palicourea species are distylous.

Heterostyly is a genetic polymorphism in which plant populations are composed of two (distyly) or three (tristyly) floral morphs that differ reciprocally in the heights at which stigmas and anthers are positioned in the flowers (Barrett 1990). Other traits commonly associated with heterostyly are self and intra-morph incompatibility and an array of ancillary floral polymorphisms (Barrett 1990). Heterostyly has been reported in at least 28 angiosperm families (Barrett et al. 2000); Rubiaceae is one particularly important family in this respect, containing hundreds of heterostylous species (Barrett et al. 2000).

In the Upper Paraná River floodplain of Brazil, Rubiaceae is among the most diverse families, including at least 22 species or about $5 \%$ of the local phanerogamic flora (Souza et al. 1997). Palicourea crocea (Sw.) Roem. et Schult. is a common heterostylous shrub in the understory of riparian forest of that region (Souza et al. 1997, Souza and Souza 1998). Flowers are visited by hummingbirds (Souza and Souza 1998) and P. crocea appears to be one of the few local species displaying floral features related to hummingbird pollination. Hummingbirds are the most specialized nectarivorous birds and represent both the ecologically and numerically dominant group in bird-plant interactions in the Neotropics (Stiles 1981). Considered important components of the Neotropical fauna, hummingbirds visit and pollinate many plant species in Brazil (Mendonça and Anjos 2003).

In this paper, we report floral morphology, nectar features, and hummingbird visitation to $P$. crocea in the Upper Paraná River floodplain (Brazil).
The main goals of the current study were to evaluate: (1) morphological components of heterostyly in P. crocea; (2) nectar production and standing crop patterns throughout the day; (3) response of flowers to nectar removal; and (4) behavior and visitation patterns of hummingbirds to flowers.

\section{MATERIALS AND METHODS}

Palicourea crocea bears terminal inflorescences that emerge from the foliage on flexible peduncles and are easily accessible for animals in hovering flight. Flowers are scentless, with yellow to reddish tubular corollas that contrast with the green foliage. The inflorescence branches are also brightly colored, varying from orange to red. Nectar accumulates in the enlarged basal part of the corolla tube and an internal ring of trichomes encloses the nectar chamber, separating this from the anthers and stigma (see also Souza and Souza 1998). Vouchers of Palicourea crocea have been deposited at the Nupélia herbarium - Universidade Estadual de Maringá (HNUP 2453-2456).

The study was carried out on Porto Rico island (103 ha; $22^{\circ} 45^{\prime} \mathrm{S}$ and $53^{\circ} 15^{\prime} \mathrm{W}$ ), between the States of Paraná and Mato Grosso do Sul, Brazil. The island lies in the Upper Paraná River, a conservation unit [Área de Preservação Ambiental (APA) das Ilhas e Várzeas do Rio Paraná (Environmental Preservation Area)], at an elevation of $230 \mathrm{~m}$ a.s.l. According to the Köeppen system, the region's climate is classified as Cfa (tropical-subtropical) with an average annual temperature of $22^{\circ} \mathrm{C}$ (summer average $26^{\circ} \mathrm{C}$, and winter average $17^{\circ} \mathrm{C}$ ), and an average annual rainfall of $1500 \mathrm{~mm}$ (Eletrosul 1986). The area lies within the phytoecological region of Seasonal Semideciduous Forest (Souza et al. 1997), in the extreme west portion of the Atlantic Forest in Brazil (Simões and Lino 2002). Porto Rico island has been heavily deforested, leaving only 3 small forest fragments which occupy about 6.17 ha. The study was conducted in a remnant of riparian forest. At the study site, $P$. crocea is especially abundant in areas subject to flooding, where individuals are usu- 
ally clumped in distribution and sometimes occur in dense patches. A population of $P$. crocea with more than 100 individuals in a single patch was chosen for observations.

Floral traits were observed in the field. Floral measurements (Fig. 1) were made on fresh or fixed material (70\% ethanol). A digital caliper (accuracy to $0.01 \mathrm{~mm}$ ) was used to measure: (1) corolla length, (2) stigma height (with stigma lobes closed and held vertically), (3) anther height (to tip of anther), (4) stigma lobes length, and (5) anther length. The difference between stigma and anther heights (6) was calculated for each flower as the absolute value of anther height less stigma height (Faivre and McDade 2001). Time and length of anthesis were observed in 15 flowers from four individuals tagged at the bud stage.

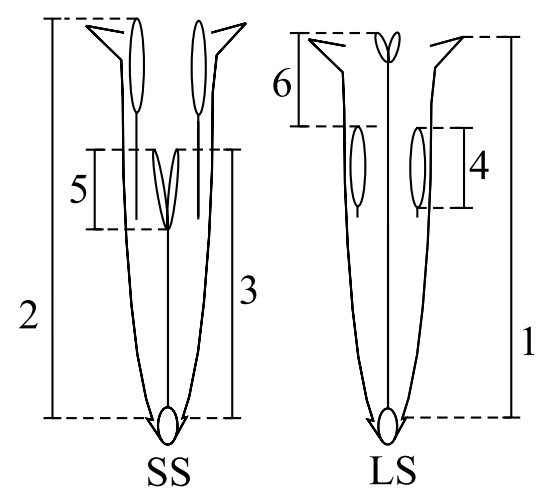

Fig. 1 - Schematic drawing of short-styled (SS) and long-styled (LS) flowers of Palicourea crocea, and measurements made from them. Numerals correspond to the following measurements for both morphs: (1) corolla length, (2) anther height, (3) stigma height, (4) anther length, (5) stigma lobe length, and (6) difference between stigma and anther height. After Faivre and McDade (2001).

Flowering and fruiting of $P$. crocea were recorded for 50 individually marked shrubs every month, from February 2002 to March 2003. Each month, we counted the number of individuals with buds or developing inflorescences, open flowers, immature fruits, and ripe fruits. Flowering and fruiting peaks were defined based on the number of individuals bearing open flowers and fruits, re- spectively. The number of open flowers per plant was estimated by counts at 23 individuals during the flowering peaks of 2001 and 2002. The ratio of floral morphs in the studied population was evaluated based in 40 of the 50 marked individuals.

Cumulative nectar production during the day was assessed on 19 October 2002. Flowers were bagged in mosquito netting at bud stage to prevent visits from animals and nectar was sampled at twohour intervals beginning at $0800 \mathrm{~h}$ and continuing until 1800h. Flowers were sampled destructively, thus different sets of flowers ( $N=9-13$ flowers) were used in each removal period. We measured nectar volume per flower (in $\mu \mathrm{l}$ ) and sugar concentration (\% sucrose, wt/total wt) in all samples. The former was obtained by using graduated microliter syringes (Hamilton) and sugar concentration was measured with a hand refractometer (Atago, $0-32 \%)$. The amount of sugar produced was denoted in mg per flower after Bolten et al. (1979) and converted to joules assuming that $1 \mathrm{mg}$ of sugar yields 16.8 joules (Dafni 1992). The results of cumulative nectar production yielded data to indicate the maximum amount of nectar that unvisited flowers could produce throughout the day. We did not observe any mites in flowers. Thus, nectar values obtained in the study are likely to represent the actual values of nectar produced. Nectar standing crop, the amount of nectar available to visitors, was evaluated three times a day $(0800,1300$, and 1800h) in flowers exposed to foragers $(N=12-16$ different flowers per sample). Samples were taken on 18 October and repeated on 24 October.

The response of flowers of $P$. crocea to nectar removal was evaluated on 29 October. Flowers ( $N=10-13)$ were subjected to one of the following three treatments, simulating legitimate visits by pollinators (see McDade and Weeks 2004b): (1) removal of nectar at 2 -h intervals between $0800 \mathrm{~h}$ and 1800h; (2) removal at 5-h intervals $(0800,1300$, and 1800h); and (3) removal of nectar only once, at $1800 \mathrm{~h}$ (control). For each removal schedule, total nectar production was the sum of volumes removed over the course of the day, whether six, three or one 
times. In all treatments flowers were tagged at bud stage for identification and bagged to prevent visits from animals. Nectar was extracted without removing the flowers from the plant, thus extreme care was taken to avoid damaging the nectaries or other floral structures. The repeated nectar samples also allowed us to observe the pattern of nectar secretion for comparison to the cumulative nectar data.

Observations were carried out in November 2001 and from October to November 2002 (from 0700-1800h), for a total of 87 hours. Hummingbirds were observed directly or with binoculars and photographed for analyses of their visiting behavior. Identification was based on Grantsau (1988). We recorded hummingbird species, the time birds entered and left the floral patch, the duration of each foraging bout, the number of flowers probed per bout, the way hummingbirds removed the nectar and the height of inflorescences visited. All agonistic interactions observed were also recorded. Visitation rates were defined as the number of visits recorded in relation to the total time of observation, and expressed in bouts per hour.

All data were tested a priori for normality (Shapiro-Wilk's test) and homogeneity of variances (Levene's test). Parametric statistics were used whenever possible. Differences in morphological attributes, nectar volume, and nectar concentration between floral morphs of Palicourea crocea were evaluated by $t$-test. The Chi-square test $\left(\chi^{2}\right)$ was used to evaluate the proportion of individuals in the studied population with flowers of each morph. Nectar production and standing crops at different times of the day were compared by analyses of variance (one-way ANOVA or Kruskal-Wallis nonparametric ANOVA). The effects of nectar removal on total volume of nectar produced by the sets of flowers submitted to different removal schedules were compared by one-way ANOVA. Differences in rates of hummingbird visitation to $P$. crocea among time intervals were evaluated using the Chi-square test. The Mann-Whitney $U$-test was used to compare the duration of each feeding bout and the number of flowers probed per bout by different hum- mingbird species. Hummingbird body mass data were obtained in Grantsau (1988).

\section{RESULTS}

Palicourea crocea flowers are distylous; stigmaanther position divided the plants into two distinct morphs: short-styled (SS) flowers, with a short style and long stamens, and long-styled (LS) flowers, with the complementary arrangement. The studied population had an approximately $1: 1$ ratio of the morphs $\left(\chi^{2}=0.10, \mathrm{df}=1, P=0.75 ; N=40\right)$. The stylestamen dimorphism on $P$. crocea flowers was accompanied by other inter-morph variations in corolla length, anther length, and stigma lobe length (Table I). Short-styled flowers had significantly longer corollas and anthers than LS flowers. Stigma lobes were notably distinct in the two morphs regarding both length and form; SS had straight, longer stigma lobes, whereas LS flowers had curved, shorter stigma lobes. We did not observe strict reciprocity in the position of stigma and anthers between floral morphs; the difference between heights of stigma and anthers within individual flowers was greater for SS than LS flowers (Table I).

Anthesis was diurnal and seemed to be synchronous. P. crocea flowers were opened at dawn at which time pollen and nectar were already available. Each individual flower lasted for approximately one day. After flower opening, corollas become progressively more reddish. Next morning, the corollas, now slightly wilted, had fallen from the plant or could be readily dislodged by touch.

The main blooming period of $P$. crocea was during the rainy season, from October to December. The peak was in November when up to 90 percent of the individuals bore buds or developing inflorescences and about 68 percent of them had open flowers $(N=50)$. However, a few plants flowered at different times and throughout the year a few individuals could be found in flower (Fig. 2). Each day, one to ten flowers opened per inflorescence and, during the blooming peak, a mean of $51.8( \pm 55.2 \mathrm{SD})$ flowers per plant opened each day 
TABLE I

Floral dimensions (mm; measurements taken as indicated in Fig. 1) and results of $t$-test for long-styled (LS) and short-styled (SS) morphs of Palicourea crocea in the Upper Paraná River floodplain. SD: standard deviation. $* \mathbf{P}<0.01$.

\begin{tabular}{ll|c|c|c|c|c}
\hline \multirow{2}{*}{ F l o r a l d i m e n s i o n } & \multicolumn{2}{|c|}{ LS } & \multicolumn{2}{|c|}{ SS } & \multirow{2}{*}{$t$} \\
\cline { 2 - 6 } & & Mean & SD $(N)$ & Mean & SD $(N)$ & $t$ \\
\hline 1 & Corolla length & 18.26 & $2.39(47)$ & 20.66 & $2.39(40)$ & $4.67^{*}$ \\
\hline 2 & Anther height (to tip anther) & 13.02 & $1.24(47)$ & 18.81 & $1.96(40)$ & $16.69^{*}$ \\
\hline 3 & Stigma height & 17.63 & $1.73(47)$ & 12.38 & $1.11(40)$ & $-16.54^{*}$ \\
\hline 4 & Anther length & 3.91 & $0.24(31)$ & 4.31 & $0.39(21)$ & $4.57^{*}$ \\
\hline 5 & Stigma lobe length & 1.91 & $0.51(30)$ & 3.73 & $0.61(22)$ & $11.71^{*}$ \\
\hline 6 & Anther/stigma separation & 4.61 & $1.13(40)$ & 6.43 & $1.79(47)$ & $5.77^{*}$ \\
\hline
\end{tabular}

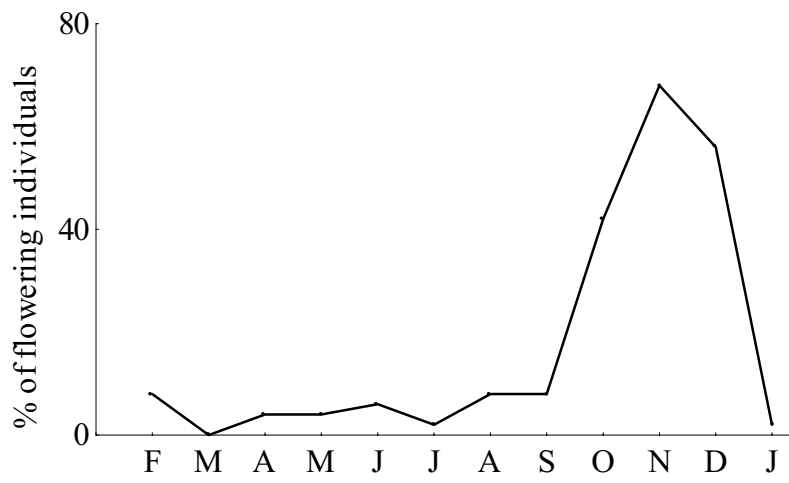

Fig. 2 - Flowering phenology of Palicourea crocea (percent of individuals with flowers, $N=50)$ in the Upper Paraná River floodplain, Brazil.

( $N=23$ plants). However, the numbers of inflorescences and open flowers varied widely among individuals ( $C V=100.8 \%)$ and some plants had as many as 200 open flowers per day. There was no significant variation in the number of open flowers per individual between 2001 and 2002 flowering peaks ( $U=54, P=0.698)$. The fruits are green when immature, but turn purplish-black when ripe. The fruiting period started in November and extended until March. In December, about 76 percent of the marked individuals had green fruits and, in February, more than 95 percent of them had ripe fruits.

Cumulative nectar production in bagged flowers of $P$. crocea during the day is shown in Table II. Most of daily nectar volume was secreted before 1000h. Mean sugar concentration remained rela- tively constant throughout the day. By the end of the day, bagged flowers accumulated a mean $( \pm$ SD) of $14.6 \pm 4.2 \mu \mathrm{l}$ of nectar with a mean sugar concentration of $24.4 \pm 1.5 \%$, corresponding to an average daily production of 66.5 joules per flower. Long-styled and short-styled flowers produced similar nectar volumes ( $t=0.28, P=0.78 ; N=8 \mathrm{SS}$ and $5 \mathrm{LS})$ and concentrations ( $t=1.40, P=0.19)$. Thus, results of all nectar samples for SS and LS flowers are presented together. Average nectar volume per flower did not differ statistically among sets of flowers submitted to different removing schedules (Table III).

In flowers exposed to foraging animals, nectar standing crop was almost $50 \%$ less than in bagged flowers, presumably due to consumption by visitors. 
TABLE II

Cumulative nectar production (volume and concentration) in Palicourea crocea flowers throughout the day in the Upper Paraná River floodplain. SD: standard deviation; CV: coefficient of variation (\%). K-W/ANOVA: results of Kruskal-Wallis $\left(\chi^{2}\right)$ or one-way ANOVA $(F)$.

\begin{tabular}{|c|c|c|c|c|c|c|c|}
\hline \multirow{2}{*}{ Nectar Feature } & \multicolumn{6}{|c|}{ Time of day (h) } & \multirow{2}{*}{ K-W/ANOVA } \\
\hline & 0800 & 1000 & 1200 & 1400 & 1600 & 1800 & \\
\hline \multicolumn{8}{|l|}{ Joules per flower } \\
\hline Mean & 47.46 & 68.92 & 68.19 & 67.88 & 72.80 & 66.46 & $\chi^{2}=13.96$ \\
\hline $\mathrm{SD}$ & 9.53 & 17.18 & 22.98 & 21.24 & 24.70 & 20.66 & $\mathrm{df}=5$ \\
\hline $\mathrm{CV}$ & 20.08 & 24.93 & 33.71 & 31.29 & 33.93 & 31.08 & $P=0.016$ \\
\hline $\mathrm{N}^{\mathrm{a}}$ & 14 & 11 & 9 & 11 & 10 & 13 & \\
\hline \multicolumn{8}{|l|}{ Volume $(\mu \mathrm{l})$} \\
\hline Mean & 10.61 & 14.89 & 14.25 & 14.89 & 16.03 & 14.63 & $\chi^{2}=13.71$ \\
\hline $\mathrm{SD}$ & 1.96 & 3.75 & 5.21 & 4.30 & 4.32 & 4.22 & $\mathrm{df}=5$ \\
\hline $\mathrm{CV}$ & 18.47 & 25.18 & 36.56 & 28.88 & 26.95 & 28.84 & $P=0.018$ \\
\hline \multicolumn{8}{|l|}{ Concentration $(\%)$} \\
\hline Mean & 24.16 & 25.02 & 25.98 & 24.38 & 24.11 & 24.39 & $F_{5,62}=1.41$ \\
\hline $\mathrm{SD}$ & 1.27 & 1.58 & 1.44 & 2.63 & 2.62 & 1.51 & $P=0.23$ \\
\hline $\mathrm{CV}$ & 5.26 & 6.31 & 5.54 & 10.79 & 10.89 & 6.19 & \\
\hline
\end{tabular}

${ }^{\text {a }}$ Sample sizes are the same for joules per flower, volume, and concentration.

TABLE III

Effect of nectar removal on total nectar production in Palicourea crocea in the Upper Paraná River floodplain. Flowers were subject to six (Group 1), three (Group 2) or one (Group 3; control) removals of nectar at regular intervals between $0800 \mathrm{~h}$ and $1800 \mathrm{~h}$. SD: standard deviation. Means were compared using one-way ANOVA.

\begin{tabular}{c|c|c|c|c}
\hline Total nectar production & Group 1 & Group 2 & Group 3 & ANOVA \\
\hline Mean & 14.07 & 15.56 & 14.63 & $F=0.31$ \\
SD & 4.78 & 3.92 & 4.22 & $P=0.74$ \\
N & 10 & 10 & 13 & \\
\hline
\end{tabular}

Both nectar volume, concentration, and mean energy content (joules per flower) did not change significantly over the day (Table IV). As shown by CVs, there was a high variation among flowers at any one time regarding volume and joules per flower. The number of flowers containing no nectar increased throughout the day. By the end of the day $(1800 \mathrm{~h})$, at least $40 \%$ of the sampled flowers had no nectar and, in contrast, a few flowers that presumably had not recently been visited had standing crops with up of $3 \mathrm{mg}$ of sugar. Sugar concentrations on October 18 were lower than on October 24 ( $U=198$; $P<0.01)$; this probably occurred because temperature was lower in the first day $\left(25^{\circ} \mathrm{C}\right)$ than in the second day of sampling $\left(30^{\circ} \mathrm{C}\right)$.

Three hummingbird species were observed: the Gilded Sapphire (Hylocharis chrysura Shaw, 1812), the Black-throated Mango (Anthracothorax 


\section{TABLE IV}

Nectar standing crop in Palicourea crocea flowers in the Upper Paraná River floodplain at different times of day. SD: standard deviation; CV: coefficient of variation (\%). K-W: results of Kruskal-Wallis $\left(\chi^{2}\right)$ comparisons.

\begin{tabular}{|c|c|c|c|c|}
\hline \multirow{2}{*}{ Standing crop of nectar } & \multicolumn{3}{|c|}{ Time of day $(\mathrm{h})$} & \multirow{2}{*}{$\mathrm{K}-\mathrm{W}$} \\
\hline & 0800 & 1300 & 1800 & \\
\hline \multicolumn{5}{|l|}{18 October 2002} \\
\hline \multicolumn{5}{|l|}{ Joules per flower } \\
\hline Mean & 31.76 & 37.45 & 29.05 & $\chi^{2}=2.00$ \\
\hline $\mathrm{SD}$ & 26.3 & 32.18 & 33.12 & $\mathrm{df}=2, P=0.37$ \\
\hline $\mathrm{CV}$ & 82.81 & 95.93 & 114.01 & \\
\hline $\mathrm{N}^{\mathrm{a}}$ & 12 & 12 & 12 & \\
\hline \multicolumn{5}{|l|}{ Volume $(\mu \mathrm{l})$} \\
\hline Mean & 6.92 & 8.69 & 6.69 & $\chi^{2}=0.89$ \\
\hline $\mathrm{SD}$ & 5.22 & 7.26 & 7.34 & $\mathrm{df}=2, P=0.64$ \\
\hline $\mathrm{CV}$ & 75.43 & 83.54 & 109.71 & \\
\hline \multicolumn{5}{|l|}{ Concentration $(\%)$} \\
\hline Mean & 23.62 & 22.21 & 23.20 & $\chi^{2}=4.52$ \\
\hline SD & 3.07 & 5.34 & 3.26 & $\mathrm{df}=2, P=0.10$ \\
\hline $\mathrm{CV}$ & 13.00 & 24.04 & 14.05 & \\
\hline $\mathrm{N}^{\mathrm{b}}$ & 10 & 9 & 7 & \\
\hline \multicolumn{5}{|l|}{24 October 2002} \\
\hline \multicolumn{5}{|l|}{ Joules per flower } \\
\hline Mean & 35.69 & 31.64 & 23.66 & $\chi^{2}=2.24$ \\
\hline $\mathrm{SD}$ & 18.96 & 19.50 & 22.70 & $\mathrm{df}=2, P=0.33$ \\
\hline $\mathrm{CV}$ & 53.12 & 61.63 & 95.94 & \\
\hline $\mathrm{N}^{\mathrm{a}}$ & 12 & 12 & 15 & \\
\hline \multicolumn{5}{|l|}{ Volume $(\mu \mathrm{l})$} \\
\hline Mean & 7.10 & 6.28 & 5.13 & $\chi^{2}=2.71$ \\
\hline SD & 3.57 & 3.79 & 4.73 & $\mathrm{df}=2, P=0.26$ \\
\hline $\mathrm{CV}$ & 50.28 & 60.35 & 92.20 & \\
\hline \multicolumn{5}{|l|}{ Concentration (\%) } \\
\hline Mean & 26.27 & 26.75 & 24.70 & $\chi^{2}=0.20$ \\
\hline $\mathrm{SD}$ & 2.20 & 1.39 & 2.93 & $\mathrm{df}=2, P=0.90$ \\
\hline $\mathrm{CV}$ & 8.37 & 5.20 & 11.86 & \\
\hline $\mathrm{N}^{\mathrm{b}}$ & 12 & 11 & 9 & \\
\hline
\end{tabular}

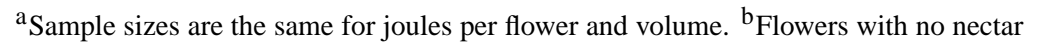
were not included in the analysis. 
nigricollis Vieillot, 1817), and the Glittering-bellied Emerald (Chlorostilbon aureoventris d'Orbigny and Lafresnaye, 1838). All three species visited flowers legitimately. Hummingbirds made a total of 169 visits in 87 hours of observation. Hylocharis chrysura and A. nigricollis were the most frequent (62.7\% and $32.5 \%$ of the total observed visits, respectively), whereas $C$. aureoventris was sporadic, accounting for only 3 percent of visits. In about 1.8 percent of the visits it was not possible to identify the bird to species. Besides hummingbirds, some unidentified robbing bees, and diurnal moths and butterflies which visitation to flowers may result in some pollen transfer were observed feeding at flowers.

Hummingbirds visited the observed clump of P. crocea at about two visits per hour. H. chrysura visited the flowers more frequently than A. nigricollis (Table V). Time of day was not related to number of visits per hour $\left(X^{2}=0.93, \mathrm{df}=10, P=0.999\right)$, given that visitation rates were relatively constant throughout the day. While probing for nectar, hummingbirds consistently touched anthers and stigmas with their bills and, due to the existence of LS and SS morphs, we observed that pollen loads were placed on two different portions in the beaks. Nevertheless, we occasionally observed $H$. chrysura individuals rubbing their bills against branches which likely removed pollen (10\% of its visits; $N=106$ ). This behavior was observed only once in a female $A$. $n i$ gricollis.

Hylocharis chrysura foraged haphazardly at flowers situated at different heights, whereas $A$. nigricollis most often visited the upper inflorescences; in only seven percent of the observed visits $(N=43)$ did individuals of $A$. nigricollis forage on low flowers ( $<1 \mathrm{~m}$ high). Body mass was related to number of flowers probed and time spent per foraging bout. The larger A. nigricollis explored a significantly higher number of flowers per bout than $H$. chrysura and, likewise, stayed longer on the floral patch (Table V).

After visiting the flowers, hummingbirds either (a) flew away from the floral patch $(H$. chrysura $=$ $41 \%$ of 73 visits, $A$. nigricollis $=59.5 \%$ of 37 vis- its) or (b) perched in shrubs or trees in the vicinity. In the second case, hummingbirds flew away soon afterwards or visited the flowers again. Only ten agonistic interactions were recorded (0.06 displacements per visit, $N=169$ ), the majority between conspecifics (7 of 10). Anthracothorax nigricollis was the dominant species in interspecific encounters $(N=2)$. Hylocharis chrysura chased a butterfly once.

No hummingbird species was recorded at the study site other than those visiting $P$. crocea. In addition to $P$. crocea, individuals of all three species were observed taking nectar from flowers of Inga vera (Mimosaceae) on the island and in adjacent areas. Hummingbird presence on the island was apparently related to the blooming periods of $P$. crocea and I. vera. Between May and July, when neither species was in flower, no hummingbirds were recorded at the study site.

\section{DISCUSSION}

The floral features of Palicourea crocea (brightcolored inflorescences, tubular corollas, scentless, dilute nectar) probably reflect adaptations to ornithophily (Faegri and van der Pijl 1979, Proctor et al. 1996), given that most are similar to those reported for other hummingbird-pollinated Rubiaceae, such as Ferdinandusa speciosa (Castro and Oliveira 2001), Manettia luteo-rubra (Passos and Sazima 1995), Psychotria nuda (Buzato et al. 2000), and other species of Palicourea (Sobrevila et al. 1983, Ree 1997, Contreras and Ornelas 1999). However, the flower size of $P$. crocea makes nectar accessible to other visitors, such as diurnal moths and butterflies, which perhaps have some participation in pollination.

We found two distinct classes of anthers and stigma height for SS and LS flowers of $P$. crocea that were accompanied by between-morph variation in ancillary features of heterostyly (corolla length, stigma lobe length, anther length). The dimorphism in style and stamen heights recorded for P. crocea, as well as the other morphological differences be- 
TABLE V

Numbers of flowers probed per foraging bout, bout length (sec.), and visitation rates (bouts per hour) for hummingbird visitors to Palicourea crocea flowers in the Upper Paraná River floodplain. M-W/t : results of Mann-Whitney $(U)$ or $t$-test $(t)$.

\begin{tabular}{c|c|c|c}
\hline & $\begin{array}{c}\text { Hylocharis } \\
\text { chrysura }\end{array}$ & $\begin{array}{c}\text { Anthracothorax } \\
\text { nigricollis }\end{array}$ & $\mathrm{M}-\mathrm{W} / t$ \\
\hline Flowers probed per bout & 14.29 & 23.31 & $U=427.0$ \\
Mean & 13.94 & 19.85 & $P=0.026$ \\
SD & 48 & 26 & \\
N & & & \\
Bout length & 31.51 & 46.54 & $U=829.0$ \\
Mean & 27.42 & 38.84 & $P=0.011$ \\
SD & 61 & 39 & \\
N & & & $t=4.01$ \\
Visitation rate & 1.22 & 0.63 & df $=20, P<0.01$ \\
Mean & 0.33 & 0.35 & \\
SD & 11 & 11 & \\
N &
\end{tabular}

tween SS and LS flowers, has been reported for other members of Palicourea (Sobrevila et al. 1983, Feinsinger and Busby 1987, Ree 1997, Taylor 1997, Contreras and Ornelas 1999) and probably promotes outcrossing (Barrett 1990). Besides the physical separation between anthers and stigma, most distylous species have an intramorph incompatibility system (Feinsinger and Busby 1987, Stone 1996). Regarding reciprocal positioning of anthers and stigma, $P$. crocea deviated significantly from the expectation for distylous species; separation between anther and stigmas was greater for SS flowers than LS flowers, perhaps due in part to the longer corolla length of SS flowers. Differences in anther/stigma separation between SS and LS flowers have been reported for other Rubiaceae such as Gaertnera vaginata (Pailler and Thompson 1997), Psychotria poeppigiana and P. chiapensis (Faivre and McDade 2001), and Sabicea cinerea (Teixeira and Machado 2004) but, in these cases, separation between anthers and stigma was greater in LS flowers than in SS flowers.

The flowering phenology of $P$. crocea resem- bles that of other hummingbird-pollinated species, such as Hamelia patens (Feinsinger 1978) and Barbacenia flava (Sazima 1977), displaying a definite blooming peak but with some flower production throughout the year. Although the main blooming period of the studied population was not long, $P$. crocea appears to represent an important nectar source for short-billed hummingbirds and other animals in the Upper Paraná River floodplain due to its abundance, numerous flowers and nectar features.

The values of nectar volume and sugar concentration in flowers of $P$. crocea are within the range of those reported previously for hummingbirdpollinated plants (Opler 1983, McDade and Weeks 2004a). Nectar characteristics did not differ significantly between SS and LS flowers; thus, they are likely to reward pollinators equally.

Plant species studied thus far are variable in their response to nectar removal by foragers. Nectar removals have been reported to stimulate, have a neutral effect, or reduce nectar secretion (Feinsinger 1978, Gill 1988, Bernardello et al. 1994, 2004, Pio- 
vano et al. 1995, Torres and Galetto 1998, Navarro 1999, Freitas and Sazima 2001, Castellanos et al. 2002, Langenberger and Davis 2002, McDade and Weeks 2004b). For P. crocea flowers, removals had no effect on reward volume; flowers submitted to different removing schedules produced similar amounts of nectar. Thus, it is likely that the rate of nectar production by flowers of $P$. crocea is unaffected by hummingbird visits. For $P$. croceaand other species with flowers that do not respond to nectar removal or have floral nectar significantly depleted by flower mites - measurements of nectar accumulation in unvisited bagged flowers provide accurate estimates of the potential energetic value of a flower to hummingbirds.

The patterns of nectar availability (standing crop) are determined by both nectar secretion and animal visitation rates (Torres and Galleto 1998). Perhaps on account of the high number of P. crocea shrubs in the clump and the fact that nectarivores usually visit only a small proportion of flowers available in large patches (e.g. Goulson 2000), nectar standing crop (although almost 50\% less than in bagged flowers), did not vary significantly throughout the day. It is also possible that the observed high variation among flowers sampled at any one hour made it difficult to detect differences.

Based on hummingbird visiting behavior and bill length in relation to flower morphology, all three species are potential pollinators of $P$. crocea. Taking into account the frequency of visits, $H$. chrysura and A. nigricollis are the most effective hummingbird pollinators. Hylocharis chrysura individuals were occasionally observed cleaning their bills by rubbing them against a branch, a behavior that could reduce pollen transfer (Ree 1997) and thus the efficiency of pollination by birds of this species.

Nectarivores are sensitive to nectar availability in flowers and can respond to variation in nectar supplies by changing their foraging behavior (e.g. Quirino and Machado 2001). In the present study, constant nectar standing crop probably allowed hummingbirds to maintain their activity (visitation rates) at $P$. crocea flowers at the same level through- out the day.

Anthracothorax nigricollis probed considerably more flowers per bout than $H$. chrysura perhaps due to its larger mass and energetic requirements. The 24-hour energy costs for a $H$. chrysura weighing $4 \mathrm{~g}$ is estimated to be $34.4 \mathrm{~kJ}$ whereas for an $A$. nigricollis weighing $7 \mathrm{~g}$ it is calculated to be $43.3 \mathrm{~kJ}$. (see McMillen and Carpenter 1977). Such values correspond to the energy supplied by 518 and $651 P$. crocea flowers each producing $66.5 \mathrm{~J}$, respectively. However, H. chrysura visited the flowers twice as frequently as A. nigricollis, which resulted in similar number of flowers probed per day $\left(X^{2}=0.24\right.$; df $=1 ; P=0.63$ ). Thus, $H$. chrysura seems to be a pollinator as suitable as A. nigricollis for P. crocea in the study site. Considering the average number of flowers that open per individual each day, hummingbirds would need to visit many shrubs in order to satisfy their energetic demands; movement of birds between shrubs should results in inter-plant pollen flow. This, associated with occurrence of distyly, may favor outcrossing.

Based on the spatial arrangement, number of flowers per plant, floral morphology and reward, P. crocea could be classified as a clumped moderate flower (sensu Feinsinger and Colwell 1978) that would chiefly attract hummingbirds that are territorialists or territory-parasites (Feinsinger and Colwell 1978). Both H. chrysura and A. nigricollis exhibited territorial behavior, such as perching near the flowers and signaling their presence by vocalizations, visual displays and, on some occasions, aggressive attacks. Agonistic displacements were, however, uncommon perhaps due to the high abundance of flowers.

On Porto Rico island, P. crocea was apparently the only plant species with floral traits related to bird pollination and flower availability was in general low. This could explain the small number of hummingbird species recorded, as well as their absence at certain times of the year. Compared to other Atlantic Forest Sites in Brazil (Sazima et al. 1996, Buzato et al. 2000), the richness of ornithophilous species in the Upper Paraná River 
floodplain appears to be low (pers. obs.), as do hummingbird species richness and abundance (Anjos and Seger 1988, Straube et al. 1996, Gimenes and Anjos 2004).

Besides P. crocea, hummingbirds were observed in the study site visiting only Inga vera, a species that does not display floral traits related to ornithophily, but appears to be another important nectar source to hummingbirds. The hummingbird visitation to $P$. crocea flowers, combined with its nectar features and the low availability of other ornithophilous plants in the study area, suggests that the species is an important resource for short-billed hummingbirds in the study area. Similarly, the activity of these birds on flowers, together with their foraging behavior and morphology, indicate that $H$. chrysura and A. nigricollis are likely important pollinators of $P$. crocea.

\section{ACKNOWLEDGMENTS}

We are grateful to M.C. Souza, M.A.S. Alves, A. Faivre and L.A. McDade for valuable comments and to Universidade Estadual de Maringá (UEM) and Núcleo de Pesquisas em Liminologia, Ictiologia e Aquicultura (Nupélia) for logistical support. This study is part of the Master thesis of L.B. Mendonça (Programa de Pós-Graduação em Ecologia de Ambientes Aquáticos Continentais - UEM) and was supported by the Conselho Nacional de Desenvolvimento Científico e Tecnológico (CNPq) through the Pesquisa Ecológica de Longa Duração (PELD) program. L. dos Anjos also thanks the Productivity in research grant from CNPq (LdA - 350054/95-9). L.B. Mendonça received a M.Sc. grant from the Coordenação de Aperfeiçoamento de Pessoal de Nível Superior (CAPES). R.M. Rossi, L. Rodrigues and W. Rodrigues provided important assistance in the field.

\section{RESUMO}

Investigamos a morfologia floral, as características do néctar e a visita de beija-flores a Palicourea crocea (Rubiaceae), uma espécie ornitófila arbustiva comu- mente encontrada no sub-bosque da vegetação ripária na planície de inundação do Alto Rio Paraná, Brasil. As flores são distílicas, sendo o dimorfismo estilete-estames acompanhado por outras variações morfológicas no comprimento da corola, altura das anteras, comprimento das anteras e comprimento e forma das papilas estigmáticas. Não foi observada reciprocidade estrita na posição dos estigmas e anteras entre flores longistilas e brevistilas. A floração da espécie ocorreu durante a estação chuvosa, de outubro a dezembro. A disponibilidade de néctar foi relativamente constante ao longo do dia, o que aparentemente possibilitou aos beija-flores visitar a planta o dia todo. O conteúdo energético de néctar por flor $(66,5 \mathrm{~J})$ e a demanda diária de energia dos beija-flores visitantes (superior a $30 \mathrm{~kJ}$ ) os obrigaria a visitar diariamente centenas de flores da espécie, o que pode aumentar o fluxo de pólen. Três espécies de beija-flores foram observadas: beija-flor-dourado (Hylocharis chrysura), beija-flor-decolete-preto (Anthracothorax nigricollis) e esmeralda-debico-vermelho (Chlorostilbon aureoventris). A freqüência de visita dos beija-flores, as características do néctar e a baixa disponibilidade de outras flores visitadas por beijaflores na área de estudo indicam que $P$. crocea é uma fonte de néctar importante para beija-flores de bico-curto no local.

Palavras-chave: interações aves-plantas, heterostilia, polinização, Mata Atlântica, vegetação ripária, conservação.

\section{REFERENCES}

Anjos L dos And SEger C. 1988. Análise da distribuição das aves em um trecho do rio Paraná, divisa entre os Estados do Paraná e Mato Grosso do Sul. Curitiba, PR, Brasil. Arq Biol Tecnol 31: 603-612.

BARRETT SCH. 1990. The evolution and adaptive significance of heterostyly. Trends Ecol Evol 5: 144-148.

BARRETt SCH, LESSON LK AND BAKER AM. 2000. The Evolution and Function of Stylar Polymorphisms in Flowering Plants. Ann Bot 85 (Suppl. A): 253-265.

Bernardello G, Aguilar R and Anderson GJ. 2004. The reproductive biology of Sophora fernandeziana (Leguminosae), a vulnerable endemic spe- 
cies from isla Robinson Crusoe. Am J Bot 91: 198-206.

Bernardello L, Galetto L and Rodriguez IG. 1994. Reproductive biology, variability of nectar features and pollination of Combretum fruticosum (Combretaceae) in Argentina. Bot J Linn Soc 114: 293-308.

Bolten AB, Feinsinger P, BAKER HG AND BAKER I. 1979. On the calculation of sugar concentration in flower nectar. Oecologia 41: 301-304.

Buzato S, Sazima M and Sazima I. 2000. Hummingbird-pollinated floras in three Atlantic Forest sites. Biotropica 32: 824-841.

Castellanos MC, Wilson P and Thomson JD. 2002. Dynamic nectar replenishment in flowers of Pentestemon (Scrophulariaceae). Am J Bot 89: 111-118.

Castro CC And Oliveira PEA. 2001. Reproductive biology of the protandrous Ferdinandusa speciosa Pohl (Rubiaceae) in southeastern Brazil. Rev Bras Bot 24: 167-172.

CONTRERAS PS AND ORnelas JF. 1999. Reproductive biology of Palicourea padifolia (Rubiaceae) a distylous shrub of a tropical cloud forest in Mexico. Plant Syst Evol 219: 225-241.

DAfNi A. 1992. Pollination ecology: a practical approach. Oxford: Oxford University Press, 272 p.

Eletrosul. 1986. Ilha Grande. Relatório de Pesquisa 4, Centrais Elétricas do Sul do Brasil, Florianópolis, $\mathrm{SC}$, Brasil, $52 \mathrm{p}$.

FAEgri K AND VAN DeR PIJL L. 1979. The principles of pollination ecology. Oxford: Pergamon Press, $248 \mathrm{p}$.

FAIVRE AF AND MCDADE LA. 2001. Population-level variation in the expression of heterostyly in three species of Rubiaceae: does reciprocal placement of anthers and stigmas characterize heterostyly? Am J Bot 88: 841-853.

FEINSINGER P. 1978. Ecological interactions between plants and hummingbirds in a tropical community. Ecol Monogr 48: 269-287.

Feinsinger P And Busby WH. 1987. Pollen carryover: experimental comparisons between morphs of Palicourea lasiorhachis (Rubiaceae), a distylous, bird-pollinated, tropical treelet. Oecologia 73: 231235.
Feinsinger P And Colwell RK. 1978. Community organization among Neotropical nectar-feeding birds. Am Zool 18: 779-795.

FREITAS L AND SAZIMA M. 2001. Nectar features in Esterhazya macrodonta, a hummingbird-pollinated Scrophulariaceae in Southeastern Brazil. J Plant Res 114: 187-191.

GILL FG. 1988. Effects of nectar removal on nectar accumulation in flowers of Heliconia imbricate (Heliconiaceae). Biotropica 20: 169-171.

Gimenes MR AND ANJos L Dos. 2004. Spatial distribution of birds on three islands in the Upper Paraná River, Brazil. Ornitol Neotr 15: 71-85.

Goulson D. 2000. Why do pollinators visit proportionally fewer flowers in large patches? Oikos 91: 485-492.

GRANTSAU R. 1988. Os beija-flores do Brasil: uma chave de identificação para todas as formas de beijaflores do Brasil. Rio de Janeiro, RJ, Brasil, Expressão e Cultura (Ed), 233 p.

LANGenberger MW AND DAVIS AR. 2002. Temporal changes in floral nectar production, reabsorption, and composition associated with dichogamy in annual caraway (Carum carvi; Apiaceae). Am J Bot 89: 1588-1598.

MaCHAdo IC AND LoIOLA MI. 2000. Fly pollination and pollinator sharing in two synchronopatric species: Cordia multispicata (Boraginaceae) and Borreria alata (Rubiaceae). Rev Bras Bot 23: 305311.

Marques-Souza AC, Absy ML, Miranda IP And KÜCHMEISTER HEC. 1993. Características de flores, néctar y visitantes de Kerianthera preclara (Rubiaceae). Rev Biol Trop 41: 483-489.

MCDAde LA AND WeEKS JA. 2004a. Nectar in hummingbird-pollinated Neotropical plants I: patterns of production and variability in 12 species. Biotropica 36: 196-215.

MCDAde LA AND WeEKS JA. 2004b. Nectar in hummingbird-pollinated Neotropical plants II: interactions with flower visitors. Biotropica 36: 216-220.

McMillen RE and CARPenter FL. 1977. Daily energy costs and body weight in nectarivorous birds. Comp Bioch Physiol 56A: 439-441.

MendonÇA LB AND AnJos L Dos. 2003. Bird-flower interactions in Brazil: a review. Ararajuba 11: 195205. 
Murcia C And Feinsinger P. 1996. Interespecific polen loss by hummingbirds visiting flower mixtures: effects of floral architecture. Ecology 77: 550-560.

NAVARRo L. 1999. Pollination ecology and effect of nectar removal in Macleania bullata (Ericaceae). Biotropica 31: 618-625.

OPLER PA. 1983. Nectar production in a tropical ecosystem. In: BentLEY B AND EliAs T (Eds), The biology of nectarines. Columbia University Press, New York, USA, p. 30-97.

Ornelas JF, JimÉnez L, GonzÁlez C And HeRNÁNDEZ C. 2004. Reproductive ecology of distylous Palicourea padifolia (Rubiaceae) in a tropical montane cloud forest. I. Hummingbird's effectiveness as pollen vectors. Am J Bot 91: 1052-1060.

PAILler T AND ThOMPSON JD. 1997. Distyly and variation in heteromorphic incompatibility in Gaertnera vaginata (Rubiaceae) endemic to La Reunion Island. Am J Bot 84: 315-327.

PASSOS L AND SAZIMA M. 1995. Reproductive biology of the distylous Manettia luteo-rubra (Rubiaceae). Bot Acta 108: 309-313.

Piovano M, Galetto L and Bernardello L. 1995. Floral morphology, nectar features and breeding system in Ruellia brevifolia (Acanthaceae). Rev Bras Biol 55: 409-418.

Proctor M, Yeo P And LACK A. 1996. The natural history of pollination. London: Harper Collins Publishers, $479 \mathrm{p}$.

QUIRINO ZGM AND MACHADO IC. 2001. Biologia da polinização e da reprodução de três espécies de Combretum Loefl. (Combretaceae). Rev Bras Bot 24: 181-193.

REE RH. 1997. Pollen flow, fecundity, and the adaptive significance of heterostyly in Palicourea padifolia (Rubiaceae). Biotropica 29: 298-308.

SAZIMA M. 1977. Hummingbird pollination of Barbacenia flava (Velloziaceae) in the Serra do Cipó, Minas Gerais, MG, Brazil. Flora 166: 239-247.

SAzima M, Buzato S AND SAZIMA I. 1996. An assemblage of hummingbird-pollinated flowers in a montane florest in southeastern Brazil. Bot Acta 109: 149-160.

Simões LP And Lino CF (EDS). 2002. Sustentável Mata Atlântica: a exploração de seus recursos florestais. São Paulo, SP, Brasil, Senac (Ed).
Sobrevila C, Ramirez N And Enrech NX. 1983. Reproductive biology of Palicourea fendleri e P. petiolaris (Rubiaceae), heterostylous shrubs of a tropical cloud forest in Venezuela. Biotropica 15: 161169.

SouzA DC AND SouzA MC. 1998. Levantamento florístico das tribos Psychotrieae, Coussareeae e Morindeae (Rubiaceae) na região de Porto Rico, alto rio Paraná. Acta Scientiarum 20: 207-212.

SouzA MC, Cislinski J And Romagnolo MB. 1997. Levantamento florístico. In: A planície de inundação do alto rio Paraná: aspectos físicos, biológicos e socioeconômicos. VAzzOLER AEAM, Agostinho AA And Hahn NS (Eds), Maringá, PR, Brasil, Eduem, p. 343-368.

STILES FG. 1981. Geographical aspects of bird-flower coevolution with particular reference to Central America. Ann Mo Bot Gard 68: 323-351.

STONE JL. 1996. Components of pollination effectiveness in Psychotria suerrensis, a tropical distylous shrub. Oecologia 107: 504-512.

Straube FC, BORNSCHEIN MR AND SCHERERNETo P. 1996. Coletânea da avifauna da região noroeste do Estado do Paraná e áreas limítrofes. $\mathrm{Cu}-$ ritiba, PR, Brasil. Arq Biol Tecnol 39: 193-214.

TAYLOR CM. 1997. Conspectus of the genus Palicourea (Rubiaceae: Psychotriae) with the description of some new species from Ecuador and Colombia. Ann Missouri Bot Gard 84: 224-262.

TeiXeIra LAG AND Machado IC. 2004. Sabicea cinerea Aubl. (Rubiaceae): distilia e polinização em um frasgmento de floresta Atlântica em Pernambuco, Nordeste do Brasil. Rev Bras Bot 27: 193-204.

Torres C AND Galetto L. 1998. Patterns and implications of floral nectar secretion, chemical composition, removal effects and standing crop in Mandevilla pentlandiana (Apocynaceae). Bot J Linn Soc 127: 207-223.

Wesseling RA, Burgers HCM AND NiJl HCMD. 2000. Bumblebee pollination of understorey shrub species in a tropical montane forest in Costa Rica. J Trop Ecol 16: 657-672. 